\title{
Conjunctival Melanoma Clinical Distant Metastasis TNM Finding v8
}

National Cancer Institute

\section{Source}

National Cancer Institute. Conjunctival Melanoma Clinical Distant Metastasis TNM

Finding v8. NCI Thesaurus. Code C140558.

A clinical finding about one or more characteristics of conjunctival melanoma, following the rules of the TNM AJCC v8 classification system as they pertain to distant metastases. 